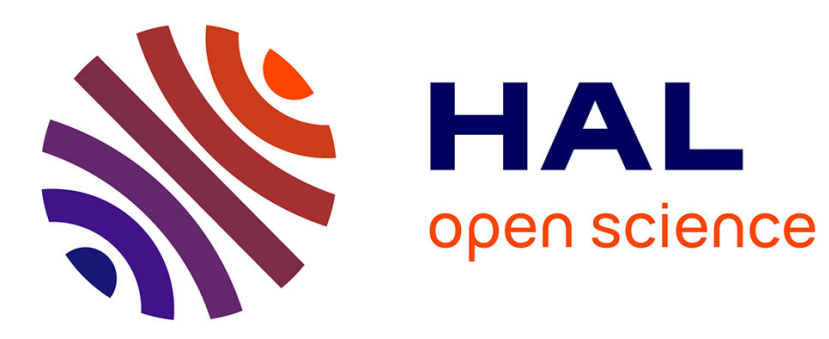

\title{
The crust of the Western Mediterranean Ridge from deep seismic data and gravity modelling
}

Cathy Truffert, Nicolas Chamot-Rooke, Siegfried Lallemant, Béatrice de Voogd, P Huchon, Xavier Le Pichon

\section{- To cite this version:}

Cathy Truffert, Nicolas Chamot-Rooke, Siegfried Lallemant, Béatrice de Voogd, P Huchon,, et al.. The crust of the Western Mediterranean Ridge from deep seismic data and gravity modelling. Geophysical Journal International, 1993, 114, pp.360-372. 10.1111/j.1365-246X.1993.tb03924.x . hal-01993162

\section{HAL Id: hal-01993162 \\ https://hal.science/hal-01993162}

Submitted on 24 Jan 2019

HAL is a multi-disciplinary open access archive for the deposit and dissemination of scientific research documents, whether they are published or not. The documents may come from teaching and research institutions in France or abroad, or from public or private research centers.
L'archive ouverte pluridisciplinaire HAL, est destinée au dépôt et à la diffusion de documents scientifiques de niveau recherche, publiés ou non, émanant des établissements d'enseignement et de recherche français ou étrangers, des laboratoires publics ou privés. 


\title{
The crust of the Western Mediterranean Ridge from deep seismic data and gravity modelling
}

\author{
C. Truffert, N. Chamot-Rooke, S. Lallemant, B. De Voogd, P. Huchon and \\ $X$. Le Pichon \\ Laboratoire de Géologie, Ecole Normale Supérieure, 24 rue Lhomond, 75231 Paris Cedex 05, France
}

Accepted 1993 January 13. Received 1993 January 13; in original form 1991 December 5

\begin{abstract}
SUMMA RY
We present a crustal cross-section of the Western Mediterranean Ridge from the African margin to the Aegean Sea constrained by the morphology of the ridge, new seismic reflection and refraction results obtained during a two-ship cruise performed in December 1988 (Pasiphae cruise), the distribution of seismicity and gravity modelling. Morphologically, the Western Mediterranean Ridge can be divided into three main units from the Sirte Abyssal Plain to the Hellenic Trench: a broád outer unit, a narrow central unit and an inner unit. The seismic front, or seaward extent of the interplate seismicity between the African lithosphere and the Cretan Arc, is located $50 \mathrm{~km}$ seaward of the Hellenic Trench. Seismicity is thus distributed widely over the innermost unit of the ridge, suggesting that brittle material is present at shallow depth beneath the inner portion of the Mediterranean Ridge. The refraction results of the Pasiphae cruise show that the crust in the Ionian Basin and beneath the outer and central units of the Western Mediterranean Ridge is oceanic and that the Moho discontinuity progressively deepens towards the Hellenic Arc, in agreement with the accretionary prism model. High velocity material occurs at shallow depth beneath the innermost unit of the ridge. Gravity modelling also indicates a significant increase in density beneath the inner unit. We consequently interpret the inner unit of the ridge as the backstop of the Western Mediterranean Ridge prism, possibly composed of Peloponnesus thrust sheets.
\end{abstract}

Key words: accretionary prism, backstop, ESP, gravity modelling, Mediterranean Ridge.

\section{INTRODUCTION}

The Mediterranean Ridge is now generally considered to be an accretionary prism similar to the Barbados Ridge Complex (Biju-Duval, Letouzey \& Montadert 1978; Le Pichon et al. 1982; Kastens 1991). In the accretionary prism model, the Ionian and Herodotus plains south of the ridge are interpreted as the 'true' trenches (i.e. the transition from the flat undeformed abyssal plain sediments to the folded sediments on the southern flank of the ridge) and the Hellenic Trenches north of the ridge are regarded as forearc basin structures. The overall structure would thus be an accretionary prism built in front of a continental backstop extending to the top of the ridge (the 'bulldozer blade' model, Le Pichon, Mascle \& Augustithis 1982). To the north, the Aegean Sea has been actively extending since at least $13.5 \mathrm{Ma}$ ago (Le Pichon \& Angelier 1979) and is still extending today as evidenced by the high level of seismic activity (Papazachos et al. 1984). The Hellenic Arc, between the Hellenic Trench and the Aegean Sea, is a non-volcanic arc which includes the Peloponnesus, Crete, Rhodes and other islands. Its basement is formed by a series of nappes (Bonneau 1984) emplaced during the Palaeogene and the Early Miocene (Hall, Audley-Charles \& Carter 1984; Robertson \& Dixon 1984). A negative free-air gravity anomaly borders the Hellenic Arc to the south (Genthon \& Souriau 1987) which can be explained by the subduction of African lithosphere.

Many uncertainties exist regarding the deep structure of the African plate beneath the ridge and the shallow structure of the accreted sediments incorporated into the prism. Related problems are the nature of the African crust beneath the ridge (oceanic versus continental), the age of formation of the prism, the location of the main décollements within the prism (Messinian, Triassic or Cretaceous layers) and the nature and position of the 


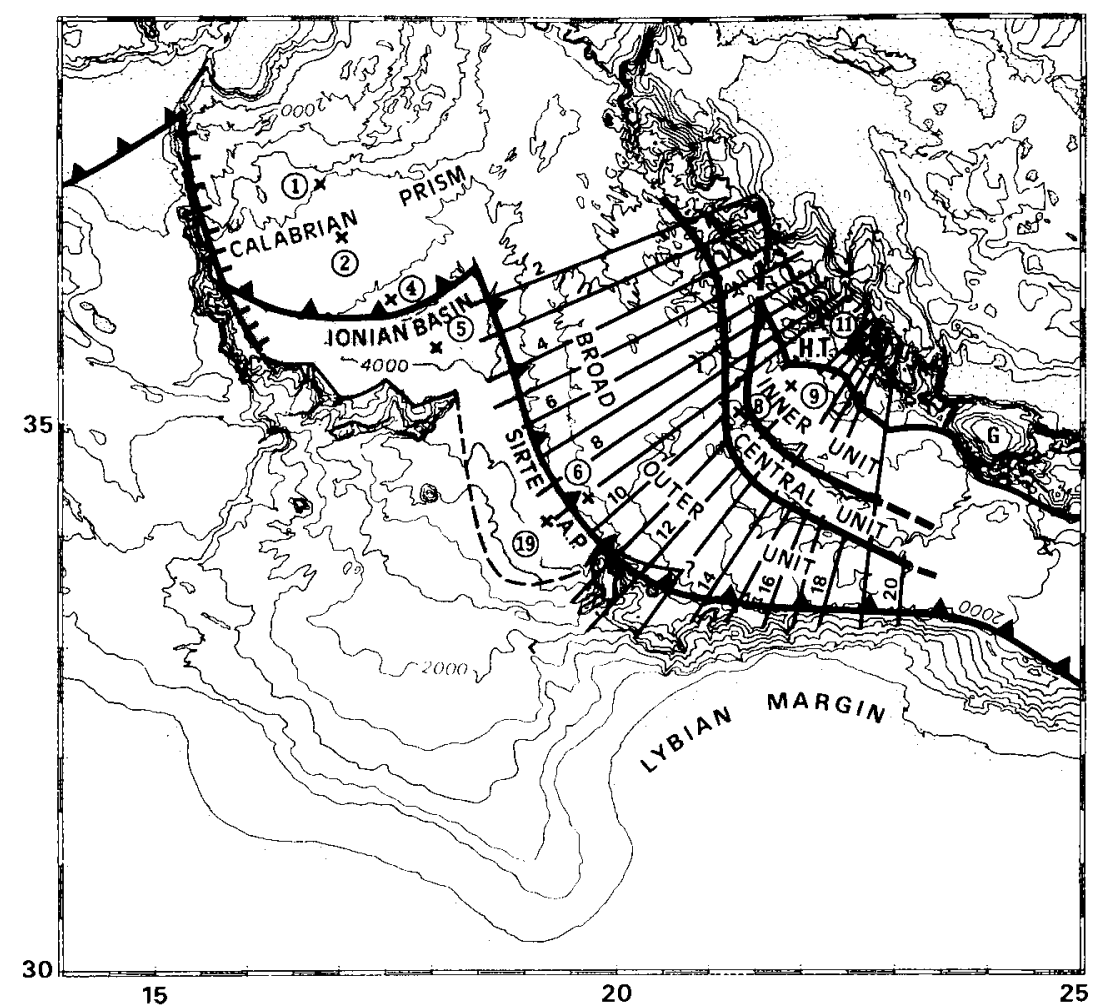

Figure 1. Bathymetric map of the western part of the Eastern Mediterranean Sea with the location of ESPs and of the 19 bathymetric profiles through the Western Mediterranean Ridge. The Malta escarpment, Sicilia sheets, the deformation front and the limit between the African oceanic crust and the African continental margin are located. The oceanic lithosphere which is not yet subducted remains in the Ionian Basin and Sirte Abyssal Plain (shaded). The ridge is separated into three units: the broad outer, the central and the inner unit H.T.: Hellenic Trench.

backstop. Many of these problems have been addressed during the last decade (see the Special Issue of Tectonophysics, X. Le Pichon et al. 1982), but the main uncertainties come from the large amount of sediments accumulated in the Eastern Mediterranean basins and accreted to the Mediterranean Ridge, and the lack of information on the deep structure of the ridge.

In the paper, we present a crustal cross-section across the western part of the Mediterranean Ridge from the African margin to the Aegean Sea constrained by the morphology of the ridge, new seismic reflection and refraction data (1988, Pasiphae cruise results), the distribution of seismicity and gravity modelling.

\section{MORPHOLOGY OF THE WESTERN MEDITERRANEAN RIDGE}

The bathymetry of the western part of the Eastern Mediterranean Sea is shown in Fig. 1, redrawn from the International Bathymetric Chart of the Mediterranean recently compiled by the Intergovernmental Oceanographic Commission (IBCM/IOC). Fig. 2 displays 19 topographic profiles across the Western Mediterranean Ridge, roughly perpendicular to the ridge. Morphologically, the ridge can be divided into three main units from the Sirte Abyssal Plain to the Hellenic Trench: a broad outer unit, a narrow central unit and an inner unit (Figs 1 and 2). The outer unit is a broad crescent topographic high about $150 \mathrm{~km}$ wide, limited to the south and west by the deformation front. It merges northwestward with the Calabrian prism and narrows

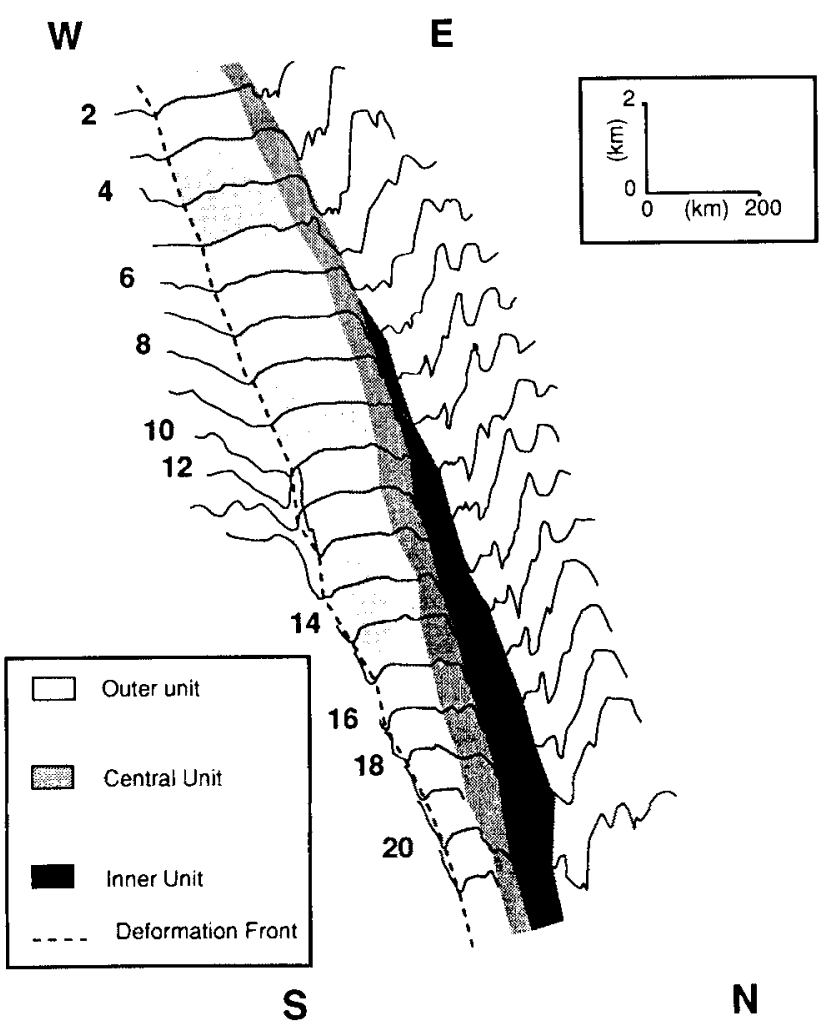

Figure 2. Bathymetric profiles across the Western Mediterranean Ridge (see location in Fig. 1). Profiles are numbered from profile 2 (westernmost) to profile 20 (easternmost). 
eastward to a width of $65 \mathrm{~km}$, as the distance from the Libyan continental margin to the Aegean Arc decreases. This unit has a characteristic convex cross-sectional shape (Fig. 2). The central unit is a narrow belt about $50 \mathrm{~km}$ wide which corresponds to the transition to the deeper inner unit (or to the Trench to the north). Eastward, this unit progressively vanishes and is absent east of $24^{\circ} \mathrm{E}$. Generally, an abrupt scarp (several hundreds metres high) marks the limit between this unit and the inner one (Fig. 2). The inner unit is a flat deeper unit southwestward of the Trench. It dies out toward the north near profile 6 . The terminology outer unit, central unit and inner unit will be used throughout the paper to refer to the different parts of the Western Mediterranean Ridge.

\section{DISTRIBUTION OF SEISMICITY}

Figure 3 shows the distribution of the seismicity around the Peloponnesus based on the ISC catalogue. Selected focal mechanisms from Taymaz, Jackson \& Westaway (1990) ( $\mathrm{n}^{\circ}$ 1 to 5 in Fig. 3) and Dziewonski, Friedman \& Woodhouse (1983a), Dziewonski et al. (1983b), Driewonski, Franzen \& Woodhouse $(1985,1986)$ ( $\mathrm{n}^{\circ} 6$ to 11 in Fig. 3) are also shown. A diffuse seismic front begins within the two inner units of the Mediterranean Ridge (Figs 1 and 3), whereas very few earthquakes occur within the broad outer unit. Beneath the broad outer unit, seismicity is present only in the mantle (below $30 \mathrm{~km}$ as shown by crosses in Fig. 3). One of these earthquakes ( ${ }^{\circ}$ 1, Fig. 3) was studied in detail by Taymaz et al. (1990). The recalculated focal depth from waveform analysis is $39 \mathrm{~km}$, and the focal mechanism

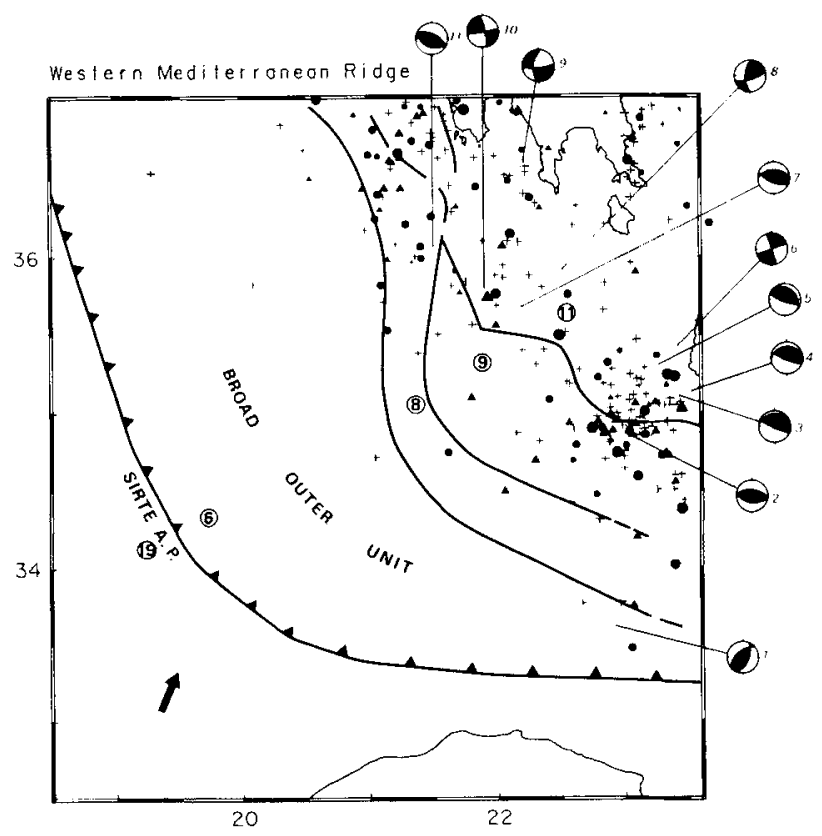

Figure 3. Map (see Fig. 1) with the distribution of seismicity from ISC catalogue and focal mechanisms (1 to 11) from Taymaz et al. (1990) ( $\mathrm{n}^{\circ} 1$ to 5) and Dziewonski et al. (1983a, 1983b, 1985, 1986) $\left(\mathrm{n}^{\circ} 6\right.$ to 11). Circles represent earthquakes situated between 1 to $10 \mathrm{~km}$ depth, triangles between 11 to $30 \mathrm{~km}$ depth and crosses deeper than $31 \mathrm{~km}$ depth. The size of the symbols indicates earthquakes magnitude. The arrow shows the direction of the convergence between the African plate and the Aegean domain. indicates a regional E-W compression of the African lithosphere beneath the outer unit of the Mediterranean Ridge. This is almost perpendicular to the relative convergence direction between Crete and Africa, which is close to $025^{\circ}$ according to the same authors (see focal mechanisms $\left.n^{\circ} 2-5,7,11\right)$. We conclude that although the state of stress in the African lithosphere beneath the Mediterranean Ridge is compressive at mantle depth, the regional $E-W$ compression exceeds any other stresses related to the convergence. This pattern does not fit with the common interpretation that the Mediterranean Ridge is the surface expression of a collision involving crustal and mantle stacking at depth (e.g. continental African margin colliding with the Cretan Arc). Although thinned continental crust may be subducting beneath the Mediterranean Ridge between the Libyan margin and Gavdos, we show in the next sections that the African lithosphere from the Sirte Abyssal Plain to the Hellenic Trench is oceanic.

The main characteristic of the seismicity distribution in Fig. 3 is its apparent widespread extent over the inner part of the Mediterranean Ridge, approximately $100 \mathrm{~km}$ seaward of the Hellenic Trench. According to Papadopoulos, Wyss \& Schmerge (1988), earthquakes published in the National Observatory of Athens Bulletin and located south of the Hellenic Trench should be shifted approximately $60 \mathrm{~km}$ in a $030^{\circ}$ direction. In spite of this shift, many of the relocated earthquakes would still be located on the inner unit of the Mediterranean Ridge $50 \mathrm{~km}$ seaward of the Hellenic Trench. This appears to be confirmed by two microseismicity studies (Pedotti 1988; Hatzfeld et al. 1989 and Hatzfeld et al. 1993) which located a few microearthquakes south of the Hellenic Trench, although the microseismicity there is less important than in the Hellenic Arc. The farthest events, $50 \mathrm{~km}$ seaward of the Hellenic Trench, are all located at depths less than $5 \mathrm{~km}$, with an uncertainty for both epicentres and depths of the order of $10 \mathrm{~km}$ (Hatzfeld et al. 1989). The accuracy of the depth determination is as given by Hatzfeld et al. (1989). The important implication is that seismically brittle, and consequently strong material is presumably present at shallow depth $(<15 \mathrm{~km})$ beneath the inner portion of the Mediterranean Ridge. Notice that no focal mechanism was determined from the microseismicity, so that those shallow earthquakes may be either compressional or extensional. Deeper earthquakes are clearly compressional $(2,3,4,5,7,11)$ with some amount of strike-slip motion $(6,8,1,10)$. The shallowest earthquake with a known focal mechanism is $\mathrm{n}^{\circ} 2$ at a depth of $18 \mathrm{~km}$ and corresponds most probably to slip between the African plate and the upper plate.

\section{NEW DEEP-SEISMIC CONSTRAINTS}

In December 1988 we performed a two-ship refraction and oblique reflection seismic survey in the Eastern Mediterranean Sea (Pasiphae cruise; de Voogd et al. 1992). 14 Expanding Spread Profiles (ESP) were shot along three sections (Fig. 1): the Calabrian prism (ESPs 1, 2, 4, and 5), the Western Mediterranean Ridge (ESPs 19,6, 8, 9 and 11) and the Eastern Mediterranean Ridge (ESPs 18, 17, 16 and 14; de Voogd et al. 1992). The cruise had two objectives: to establish the nature of the crust of the deep basins (oceanic 
Table 1. Velocity and density model for ESP 19. * indicates measured refracted velocities.

\begin{tabular}{|c|c|c|c|c|c|}
\hline ESP 19 & $(\mathrm{~km})$ & $(\mathrm{km} / \mathrm{s})$ & $(\mathrm{km} / \mathrm{s})$ & $\begin{array}{c}\text { Computed } \\
\text { density } \\
\left(\mathrm{g} . \mathrm{cm}^{-3}\right)\end{array}$ & $\begin{array}{l}\text { Used } \\
\text { density } \\
\left(\mathrm{g} \cdot \mathrm{cm}^{-3}\right)\end{array}$ \\
\hline Water & $0-3.8$ & 1.5 & 1.5 & 1.04 & 1.04 \\
\hline Sediments & $3.8-4.2$ & 1.8 & 2.0 & 1.85 & 2.20 \\
\hline \multirow[t]{2}{*}{ Evaporites } & $4.2-4.8$ & $4.4^{*}$ & 4.4 & & 2.20 \\
\hline & 4.86 .0 & 4.2 & 4.2 & & 2.20 \\
\hline \multirow[t]{2}{*}{ Sediments } & $6.0-8.2$ & 3.0 & 4.0 & 2.31 & 2.30 \\
\hline & $8.2-9.3$ & 4.2 & 4.2 & 2.38 & 2.38 \\
\hline \multirow[t]{3}{*}{ Crust } & $9.3-11.1$ & 4.9 & 5.1 & 2.49 & 2.49 \\
\hline & $11.1-14.2$ & $6.4^{*}$ & 6.6 & 2.82 & 2.82 \\
\hline & $14.2-18.4$ & $7.15^{*}$ & 7.15 & 2.98 & 2,98 \\
\hline Mantle & - & $8.5^{*}$ & - & 3.43 & 3.45 \\
\hline
\end{tabular}

Table 2. Velocity and density model for ESP 6. - indicates $^{-1}$ measured refracted velocities.

\begin{tabular}{|c|c|c|c|c|c|}
\hline EST 6 & Depth & $(\mathrm{km} / \mathrm{s})$ & $(\mathrm{km} / \mathrm{s})$ & $\begin{array}{c}\text { Computed } \\
\text { density } \\
\text { (g.cm-3) }\end{array}$ & $\begin{array}{l}\text { Used } \\
\text { density } \\
\qquad\left(\mathrm{g} \cdot \mathrm{cm}^{-3}\right)\end{array}$ \\
\hline Water & $0-3.1$ & 1.5 & 1.5 & 1.04 & 1.04 \\
\hline Sediments & $3.1-3.4$ & 1.8 & 2.0 & 1.85 & 2.20 \\
\hline \multirow[t]{2}{*}{ Evaporites } & $3.4-4.1$ & $45^{*}$ & 4.5 & & 2.20 \\
\hline & $4.1-4.4$ & 4.0 & 4.0 & & 2.20 \\
\hline \multirow[t]{2}{*}{ Sediments } & $4.4-8.1$ & 3.5 & 3.7 & 2.32 & 2.30 \\
\hline & $8.1-8.8$ & 4.1 & 4.1 & 2.37 & 2.38 \\
\hline \multirow[t]{4}{*}{ Crust } & $8.8-9.7$ & 4.5 & 4.5 & 2.41 & 2.41 \\
\hline & $9.7-12.3$ & $6.2^{*}$ & 6.5 & 2.78 & 2.78 \\
\hline & $12.3-16.2$ & $6.7^{*}$ & 6.8 & 2.88 & 2.88 \\
\hline & $16.2-19.8$ & $7.1^{*}$ & 7.1 & 2.97 & 2.97 \\
\hline Mantle & - & $8.4^{*}$ & - & 3.42 & 3.45 \\
\hline
\end{tabular}

versus continental), and to deciphere the structures of the Calabrian and Mediterranean prisms.

These refraction results establish the oceanic nature of the crust in the deep Mediterranean basins, at least in the Ionian Basin and in the Sirte Abyssal Plain (de Voogd et al. 1992).
In this paper, we use deep seismic soundings extending from the Sirte Abyssal Plain to the Hellenic Trench across the Western Mediterranean Ridge to constrain a synthetic crustal section. ESP 19 is located in the Sirte Abyssal Plain, ESP 6 on the southern flank of the Mediterranean Ridge (previously defined as the outer unit of the ridge), ESP 8 at the boundary between the central unit and the inner unit, ESP 9 on the inner unit of the ridge, and finally ESP 11 on the northern flank of the Hellenic Trench.

The details of the seismic processing and interpretation for ESPs 19 and 6 are given in de Voogd et al. (1992). Results for those two ESPs are given in Tables 1 and 2. We present here the results of ESPS 8,9 and 11.

\section{Northern flank of the central unit: ESP 8}

This ESP situated near the boundary between the central and the inner unit of the ridge is very similar to ESP 6 and 19 though the data quality is not quite as good.

\section{Sedimentary layers}

Beneath the layer of recent sea-bottom sediments $\left(1.8-2.0 \mathrm{~km} \mathrm{~s}^{-1}\right)$ a prominent refracted arrival is measured $\left(4.2 \mathrm{~km} \mathrm{~s}^{-1}\right.$ ) between $X=5 \mathrm{~km}$ and $X=10 \mathrm{~km}$ (Fig. $4 \mathrm{c}$ ). Fitting reflections observed beneath this refraction gives the velocity model of Table 3 . A velocity inversion is present beneath the $4.2 \mathrm{~km} \mathrm{~s}^{-1}$ reflected arrival as on the ESP 19 and 6 (see Tables 1 and 2). We interpret the reflector at $12.2 \mathrm{~km}$ depth as the top of the ocean crust by correlation with ESP 6.

\section{OFFSET $(\mathrm{km})$}

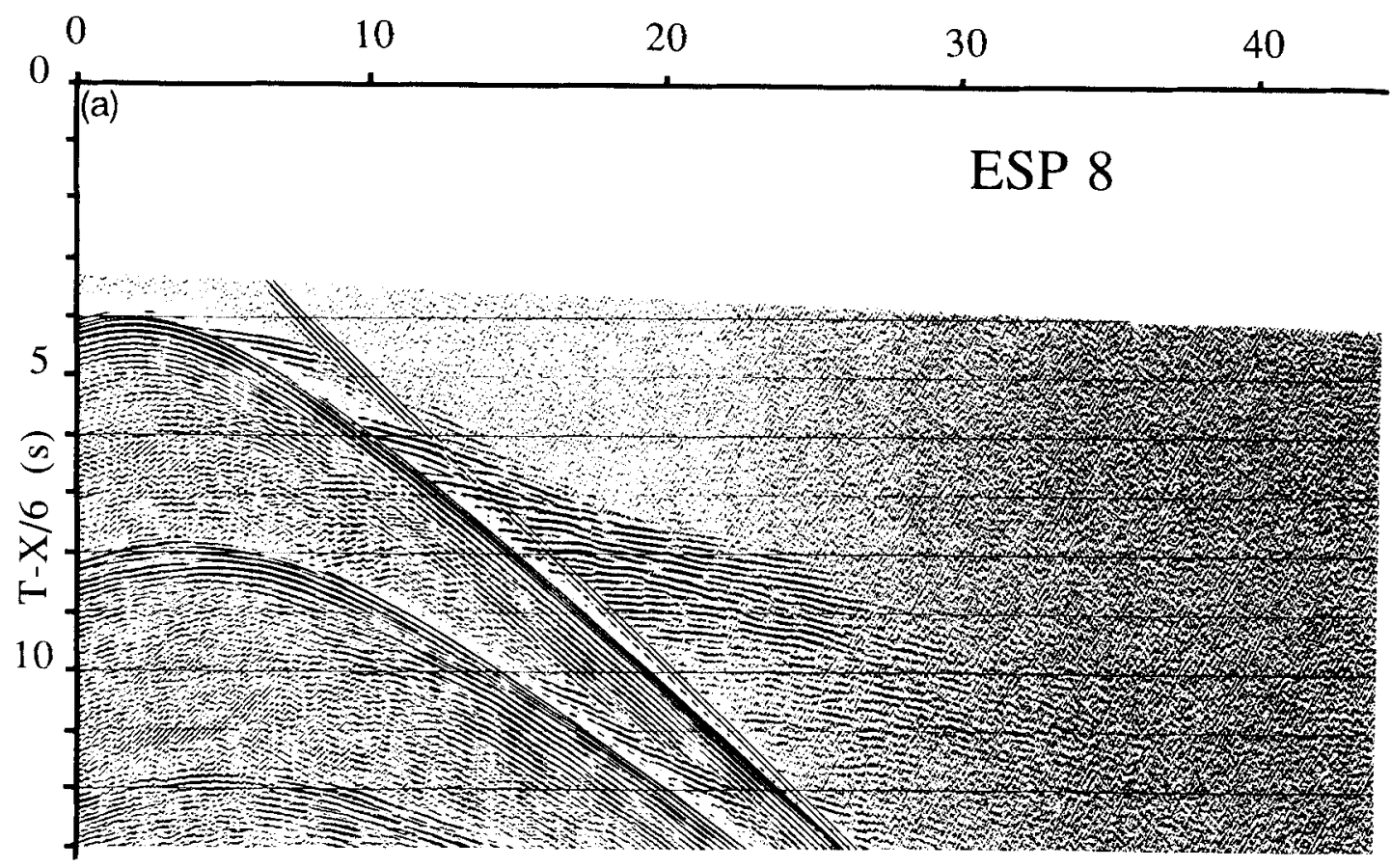

Figure 4(a). Record section for ESP 8 located on the central unit of the Western Mediterranean Ridge (Fig. 1). The traveltimes are reduced by a linear phase velocity of $6 \mathrm{~km} \mathrm{~s}$. 


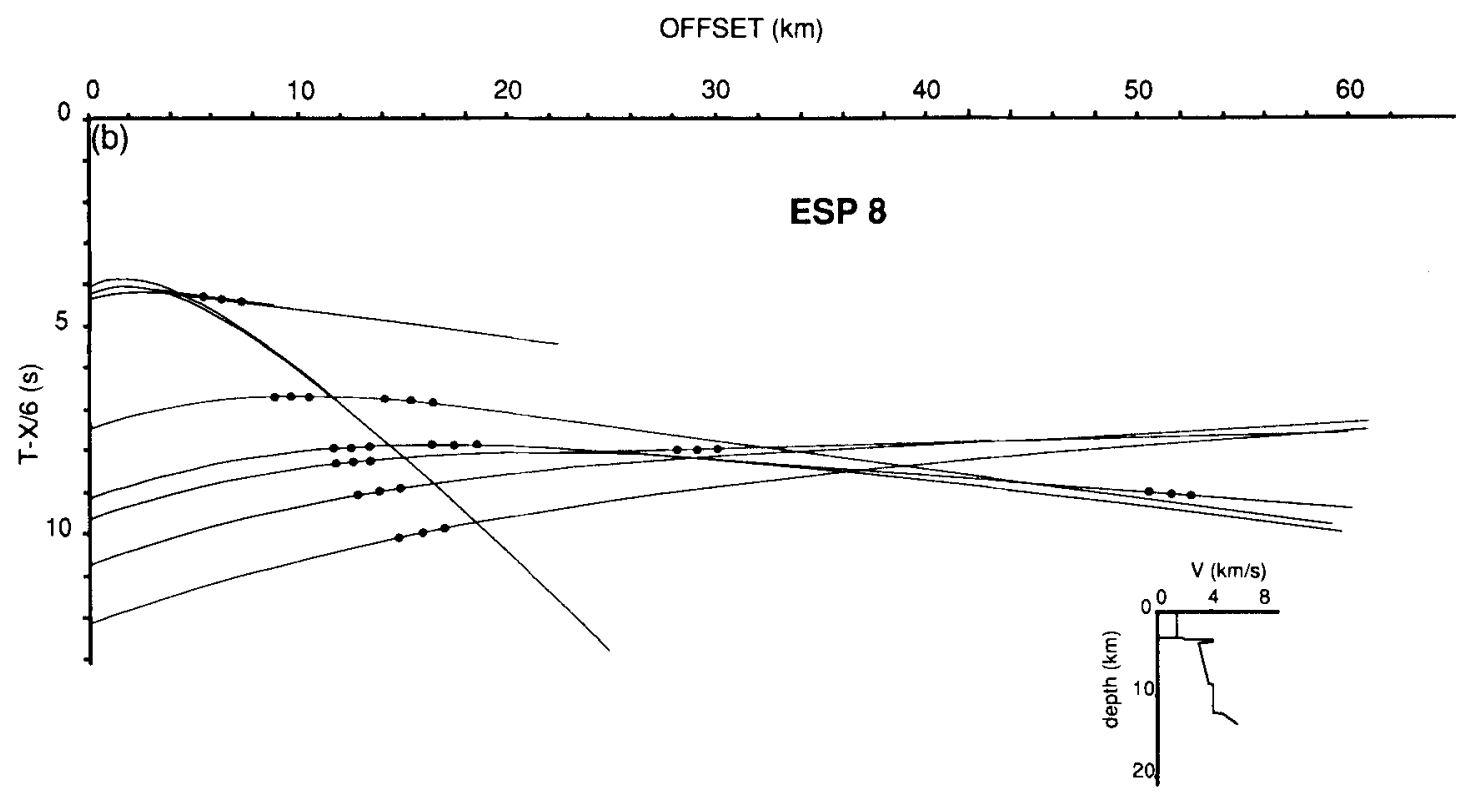

Figure 4(b). Calculated traveltime curves corresponding to the final 1-D velocity model shown on the lower right corner.

\section{Crustal layer}

The following reflected arrival observed between $X=10 \mathrm{~km}$ and $X=12 \mathrm{~km}$ gives a velocity between 4.8 and $6.0 \mathrm{~km} \mathrm{~s}^{-1}$. The velocity of this arrival is not well constrained due to its

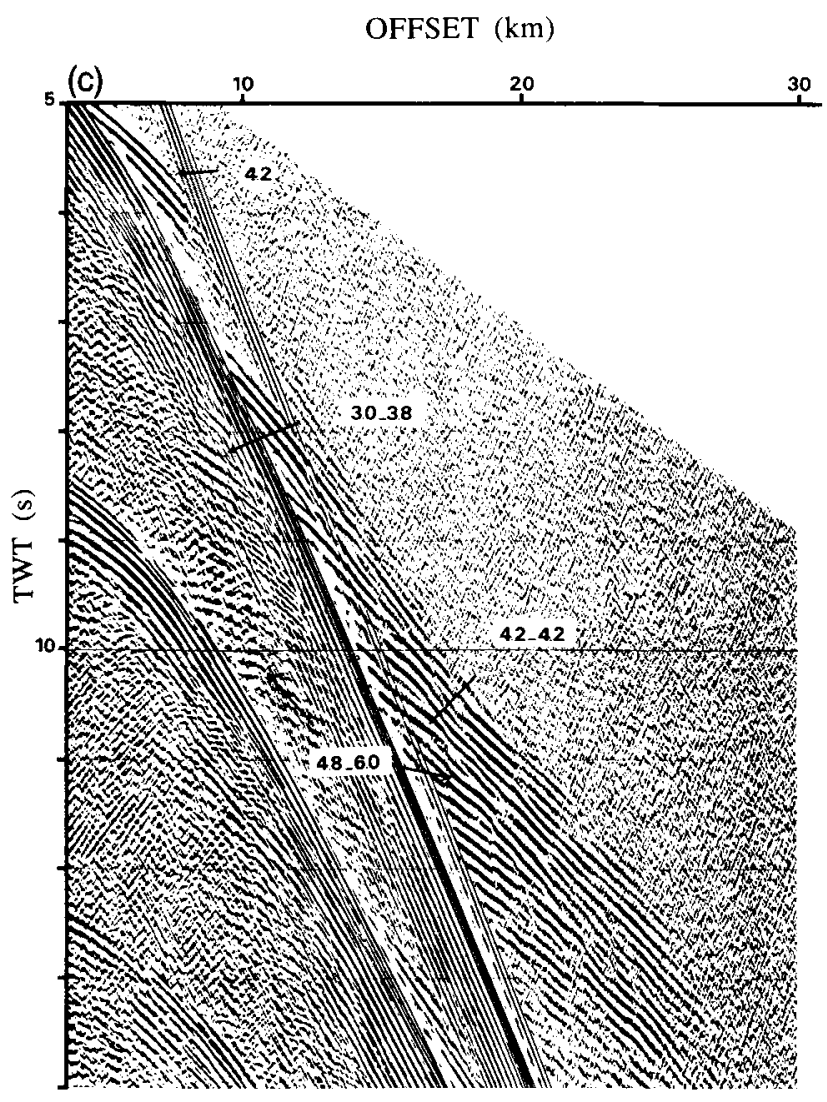

Figure 4(c). Close-up view of the record section for ESP 8. Velocity of refracted arrivals are on a white circle and reflected arrivals on a white square. Horizontal axis is distance between ships in $\mathrm{km}$ : vertical axis is the two-way traveltime in seconds.
Table 3. Velocity and density model for $\cdots$ ESP 8 . indicates measured refracted velocities.

\begin{tabular}{|c|c|c|c|c|c|}
\hline ESP 8 & $(\mathrm{~km})$ & $(\mathrm{km} / \mathrm{s})$ & $(\mathrm{km} / \mathrm{s})$ & $\begin{array}{c}\text { Computed } \\
\text { density } \\
\left(\mathrm{g} \cdot \mathrm{cm}^{-3)}\right.\end{array}$ & $\begin{array}{l}\text { Used } \\
\text { density } \\
\qquad\left(\mathrm{g} \cdot \mathrm{cm}^{-3)}\right.\end{array}$ \\
\hline Water & $0-3.0$ & 1.5 & 1.5 & 1.04 & 1.04 \\
\hline Sediments & $3.0-3.2$ & 1.8 & 2.0 & 1.80 & 2.20 \\
\hline Evaporites & $3.2-3.5$ & $4.2 *$ & 4.2 & & 2.20 \\
\hline \multirow[t]{2}{*}{ Sediments } & $3.5-8.7$ & 3.0 & 3.8 & 2.30 & 2.30 \\
\hline & $8.7-12.2$ & 4.2 & 4.2 & 2.38 & 2.38 \\
\hline Crust? & $12.2-13.5$ & 4.8 & 6.0 & 2.56 & 2.56 \\
\hline
\end{tabular}

weak extent on the $x-t$ section and consequently the crust is not well defined on this ESP.

\section{Inner unit: ESP 9}

The layer of recent sea-bottom sediments $(V=1.8$ $2.0 \mathrm{~km} \mathrm{~s}^{-1}$ ) is thinner than on ESP 8 . Between $X=5 \mathrm{~km}$ and $X=10 \mathrm{~km}$, a prominent refracted arrival is measured $\left(4.0 \mathrm{~km} \mathrm{~s}^{-1}\right.$ ) (Fig. 5c). There is no velocity inversion beneath the high-velocity arrival. The fit of reflections together with the measurement of refracted velocities $\left(4.75 \mathrm{~km} \mathrm{~s}^{-1}\right.$, $5.0 \mathrm{~km} \mathrm{~s}^{-1}, 5.5 . \mathrm{km} \mathrm{s}^{-1}$ and $6.6 \mathrm{~km} \mathrm{~s}^{-1}$ ) leads to the velocity model of Table 4. A velocity inversion $\left(4.3 \mathrm{~km} \mathrm{~s}^{-1}\right)$ is present below $11 \mathrm{~km}$.

Fitting the following reflections gives velocities of $5 \mathrm{~km} \mathrm{~s}^{-1}, 6.5-6.7 \mathrm{~km} \mathrm{~s}^{-1}$ and $7.1 \mathrm{~km} \mathrm{~s}^{-1}$. Refracted arrivals from the mantle are not seen on this ESP.

\section{Hellenic Trench (Matapan Trench): ESP 11}

This ESP was short in an area where the topography is fairly rough and consequently velocities could not be well estimated there.

The four first layers are interpreted as recent sedimentary units because of their low velocity and their high-velocity gradients. The fit of reflections together with the measurements of refracted velocities $\left(4.1 \mathrm{~km} \mathrm{~s}^{-1}, 4.6 \mathrm{~km} \mathrm{~s}^{-1}\right.$, 
OFFSET $(\mathrm{km})$

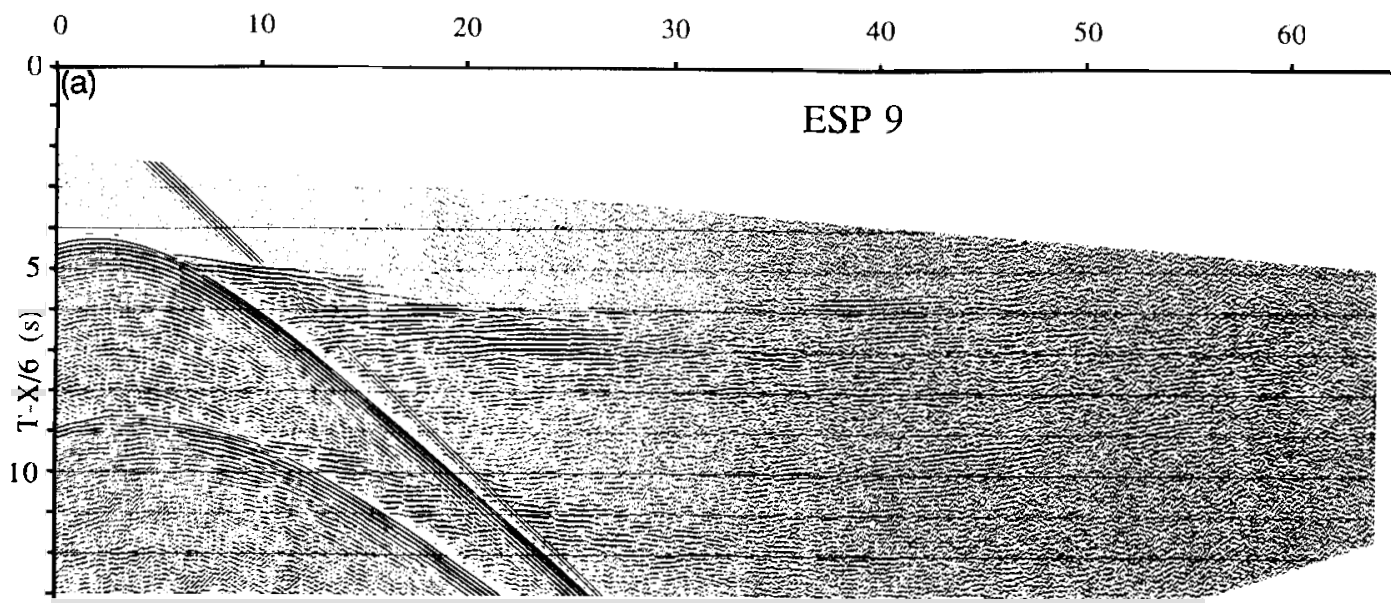

Figure 5(a). Record section for ESP 9 located on the inner unit of the Western Mediterranean Ridge (Fig. 1). The traveltimes are reduced by a linear phase velocity of $6 \mathrm{~km} \mathrm{~s}^{-1}$.

OFFSET (km)

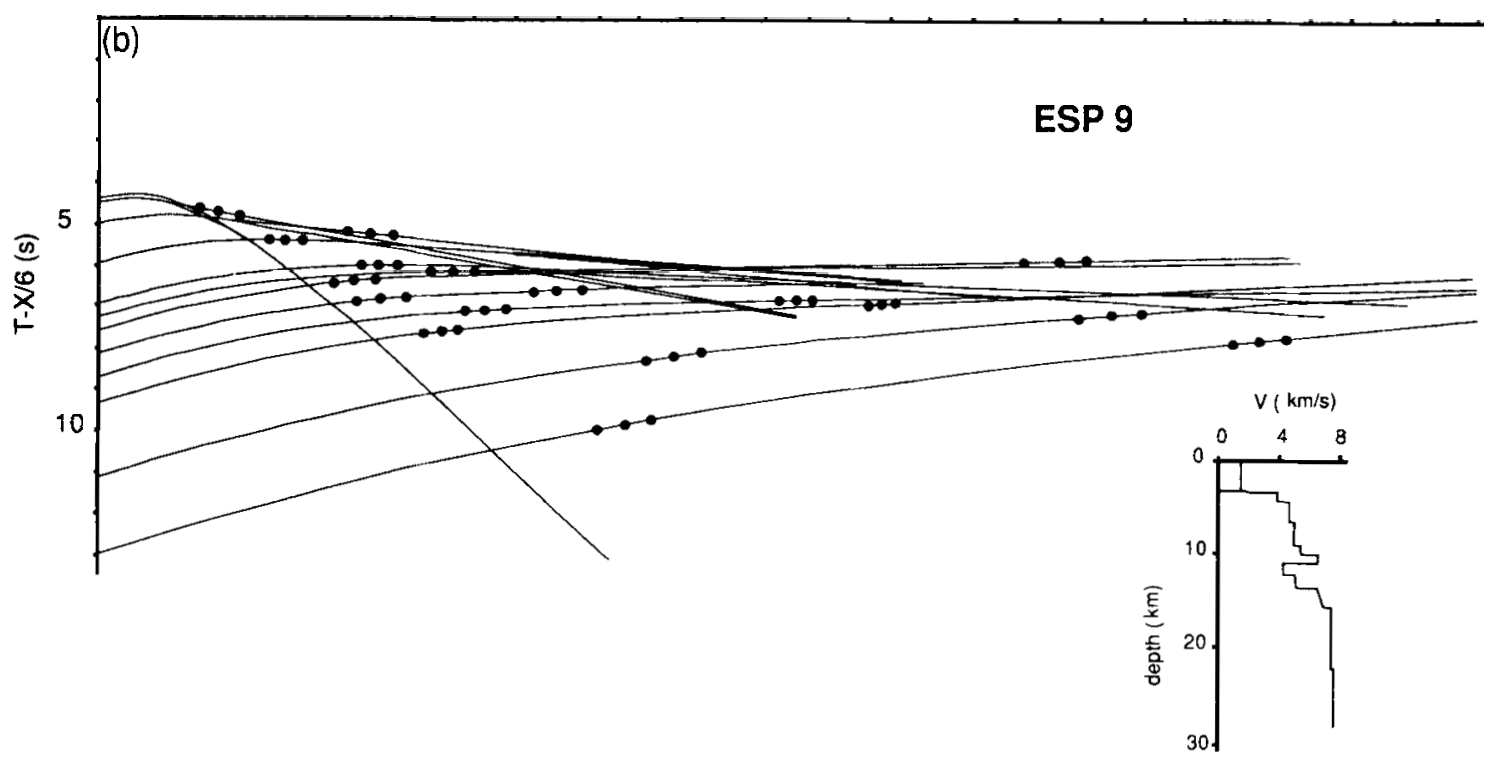

Figure 5(b). Calculated traveltime curves corresponding to the final 1-D velocity model shown on the lower right corner.

$5.9 \mathrm{~km} \mathrm{~s}^{-1}$ and $7.2 \mathrm{~km} \mathrm{~s}^{-1}$ ) lead to the velocity model of Table 5. Refracted arrivals from the mantle are not seen on this ESP.

\section{DISCUSSION OF THE PASIPHAE RESULTS}

\section{ESP 19, ESP 6 and ESP 8}

ESP 19 and ESP 6 are situated respectively in the Sirte Abyssal Plain and $20 \mathrm{~km}$ northeastward of the deformation front (Fig. 1). The crust is oceanic in the basins (Ionian basin and Sirte Abyssal Plain) and below ESP 6. The Messinian evaporitic sequence is thicker on ESP 19 (by about $800 \mathrm{~m}$ ) whereas pre-Messinian sediments are thicker on ESP 6 (by about $1 \mathrm{~km}$ ) (see Fig. 10). ESP 6 being on the
Mediterranean Ridge and ESP 19 in the basin, the thickening of sediments between these two ESPs appears to result from sediment accretion. The crust thickens by about 1 to $2 \mathrm{~km}$ between these two ESPs. This may reflect the variability of the oceanic crust thickness due to the topography.

ESPs 6 and 8 (both on the outer convex unit of the ridge) are very similar to ESP 19 shot in the Sirte Abyssal Plain. ESP 6 displays a typical oceanic crust signature, with a crustal thickness of about 8 to $10 \mathrm{~km}$, with crustal velocities of $5.5-6.5 \mathrm{~km} \mathrm{~s}^{-1}$ for oceanic layer 2 and $7.1 \mathrm{~km} \mathrm{~s}^{-1}$ for oceanic layer 3 , over a mantle with a velocity of $8.4 \mathrm{~km} \mathrm{~s}^{-1}$. The Moho discontinuity was found at a depth of $18.4 \mathrm{~km}$ in the Sirte Abyssal Plain. The Moho then progressively deepens beneath the Mediterranean Ridge, down to $19.8 \mathrm{~km}$ 


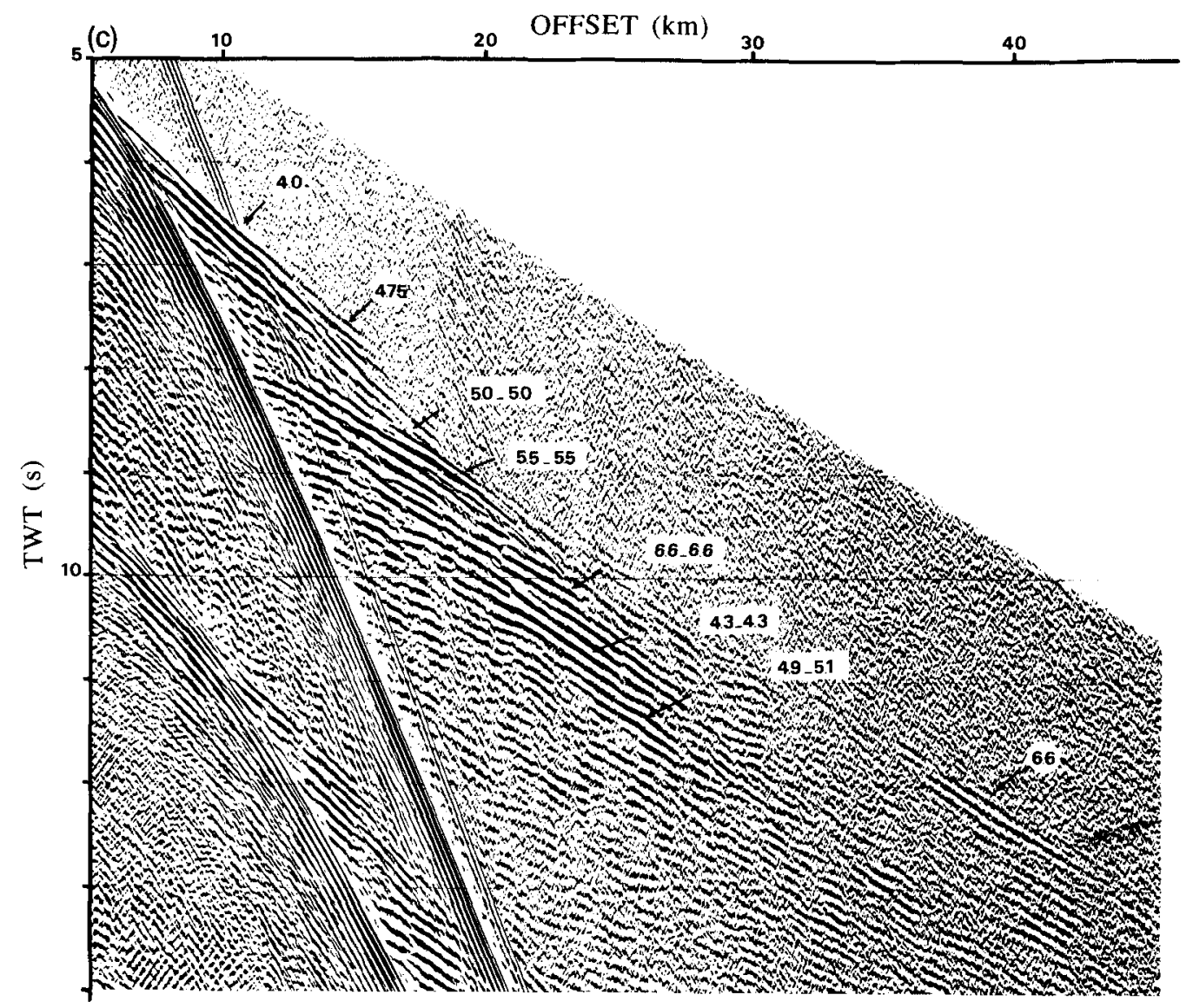

Figure 5(c). Close-up view of the record section for ESP 9. Velocity of refracted arrivals are on a white circle and reflected arrivals on a white square. Horizontal axis is distance between ships in $\mathrm{km}$; vertical axis is the two-way traveltime in seconds.

at ESP 6 (southern flank of the outer unit). On ESP 8 (northern flank of the outer unit), the oceanic crust is not well constrained by the velocity model. A Moho depth of $22.1 \mathrm{~km}$ was assigned based on a mean crustal thickness of $10 \mathrm{~km}$ found in the Sirte Abyssal Plain and beneath the outer unit of the Mediterranean Ridge and on a possible bottom of the oceanic layer $2 \mathrm{a}$ near $13.5 \mathrm{~km}$.

Several units in the sedimentary cover have been defined on the basis of the refraction results and of published reflection lines (Finetti 1976). The unconsolidated PlioQuaternary sediments are $400 \mathrm{~m}$ (ESP 19) to $300 \mathrm{~m}$ (ESPs 6 and 8$)$ thick. Below this sequence, the three ESPs $(19,6$ and 8) display a high-velocity refracted arrival ( 4.2 to $4.5 \mathrm{~km} \mathrm{~s}^{-1}$ ) corresponding to the top of the Messinian evaporites

Table 4. Velocity and density model for ESP 9. * indicates measured refracted velocities.

\begin{tabular}{|c|c|c|c|c|c|}
\hline ESP 9 & Depth & $(\mathrm{km} / \mathrm{s})$ & $\begin{array}{l}\text { Vbot } \\
\{\mathrm{km} / \mathrm{s}\rangle\end{array}$ & $\begin{array}{l}\text { Computed } \\
\text { density } \\
\left(\mathrm{g} \cdot \mathrm{cm}^{-3}\right)\end{array}$ & $\begin{array}{l}\text { Used } \\
\text { density } \\
\text { (g.cm-3) }\end{array}$ \\
\hline Water & 0.3 .3 & 1.5 & 1.5 & 1.04 & 1.04 \\
\hline Sediments & $3.3-3.4$ & 1.8 & 2.0 & 1.85 & 2.20 \\
\hline Evaporites & $3.4-4.45$ & $4.0^{*}$ & 4.0 & & 2.20 \\
\hline \multirow[t]{4}{*}{ Crust? } & $4.45-6.6$ & $4.75^{*}$ & 4.75 & 2.45 & 2.45 \\
\hline & $6.6-9.1$ & $5.0^{*}$ & 5.0 & 2.49 & 2.49 \\
\hline & $9.1-10$ & 5.5 & 5.5 & 2.58 & 2.70 \\
\hline & $10-11$ & $6.6^{*}$ & 6.6 & 2.84 & 2.70 \\
\hline Sediments & $1 \mathrm{I}-12.2$ & 4.3 & 4.3 & 2.39 & 2.39 \\
\hline \multirow[t]{3}{*}{ Crust } & $12.2-13.6$ & 5.0 & 5.0 & 2.49 & 2.49 \\
\hline & $13.6-15.7$ & 6.5 & 6.7 & 2.84 & 2.84 \\
\hline & $15.7-22.2$ & 7.1 & 7.1 & 2.97 & 2.97 \\
\hline
\end{tabular}

sequence. In the Sirte Abyssal Plain, the Messinian sequence is about $1.8 \mathrm{~km}$ thick. This sequence then progressively thins towards the Hellenic Trenches, reaching $1 \mathrm{~km}$ at ESP 6 and $0.4 \mathrm{~km}$ at ESP 8. A topographic high (or seaward slope) was thus already at the present-day location of the outer unit at the time of deposition of the Messinian unit (Montadert, Letouzey \& Mauffret 1978).

A seismic reflection profile (MS33, OGS, Finetti 1976), shows that imbricated thrusting is active within the Messinian at the toe of the prism, possibly above a décollement located at the base of the Messinian itself. However, the thickness of the Messinian is decreasing towards the crest of the ridge. Deeper accretion is indicated by the progressive thickening of the pre-Messinian sediments from ESP 19 (where it is $3.3 \mathrm{~km}$ thick) to ESP 6

Table 5. Velocity and density model for ESP 11. * indicates measured refracted velocities.

\begin{tabular}{|c|c|c|c|c|c|}
\hline ESP II & Depth & $(\mathrm{km} / \mathrm{s})$ & $(\mathrm{km} / \mathrm{s})$ & $\begin{array}{l}\text { Computed } \\
\text { density } \\
\left(\mathrm{g} \cdot \mathrm{cm}^{-3)}\right.\end{array}$ & $\begin{array}{l}\text { Used } \\
\text { density } \\
\qquad\left(\mathrm{g} \cdot \mathrm{cm}^{-3)}\right.\end{array}$ \\
\hline Water & $0-4.4$ & 1.5 & 1.5 & 1.04 & 1.04 \\
\hline \multirow[t]{6}{*}{ Sediments } & $4.4-4.6$ & 1.9 & 2.1 & 1.91 & 2.15 \\
\hline & $4.6-4.85$ & 2.3 & 2.5 & 2.10 & 2.15 \\
\hline & $4.85-5.2$ & 2.6 & 2.8 & 2.19 & 2.15 \\
\hline & $5.2-5.6$ & 2.9 & 3.1 & 2.25 & 2.33 \\
\hline & $5.6-6.4$ & $4.1^{*}$ & 4.1 & 2.37 & 2.33 \\
\hline & $6.4-7.6$ & 4.6 & 4.6 & 2.43 & 2.43 \\
\hline \multirow[t]{2}{*}{ Crust } & $7.6-9.0$ & 5.9 & 6.1 & 2.70 & 2.70 \\
\hline & $9.0-12.0$ & $7.2^{\prime \prime}$ & 72 & 3.00 & 2.92 \\
\hline
\end{tabular}


$(4.4 \mathrm{~km})$ and ESP $8(8.7 \mathrm{~km})$. On ESPs 19 and 6 , the pre-Messinian sequence is subdivided into two sequences, the top one with velocity gradient (generally from $3 \mathrm{~km} \mathrm{~s}^{-1}$ to $4 \mathrm{~km} \mathrm{~s}^{-1}$ ) and the deeper one with constant velocity $\left(4.2 \mathrm{~km} \mathrm{~s}^{-1}\right)$. Although we cannot rule out the possibility that the seismic reflection between those two sequences is a lithologic boundary, another interpretation is that this level is the Aptian shale sequence acting as a main décollement above the lower Cretaceous (Ryan, Kastens \& Cita 1982). The high-velocity layer at $4.2 \mathrm{~km} \mathrm{~s}^{-1}$ beneath would thus be the consolidated Lower Cretaceous and Jurassic limestones $(0.7 \mathrm{~km}$ thick on ESP 19 and $1.6 \mathrm{~km}$ thick on ESP 6).

The velocity models for ESPs 19,6 and 8 are thus consistent with an accretionary model. The oceanic crust of the African plate progressively deepens beneath the Western Mediterranean Ridge, with an average dip of about $1^{\circ}$ over the first $100 \mathrm{~km}$ of the prism. The topographic slope averaged over the same section of the prism does not exceed $1^{\circ}$, so that the Western Mediterranean prism is flatter than any other known prism, including Barbados and Makran. According to Davis, Suppe \& Dahlen's (1983) Coulomb wedge model, such low angles indicate the presence of very high pore-fluid pressure. The presence of fluid overpressures is demonstrated by the high level of mud diapirism found on the crest of the Mediterranean Ridge (e.g. Ryan et al. 1982; Camerlenghi et al. 1992).

\section{ESP 9 and ESP 11}

ESP 9 and 11 are located further to the north. ESP 9 is located $60 \mathrm{~km}$ northeast of ESP 8 and $70 \mathrm{~km}$ south of the Hellenic Trench, right on the inner unit of the ridge. ESP 11 is on the northern flank of Hellenic Trench. The $x-t$ sections and velocity models for those two ESPs are presented in Figs 5, 6 and 10. Both ESPS are significantly different from the other three. On ESP 9, the unconsolidated PlioQuaternary sequence is very thin, probably less than $100 \mathrm{~m}$.
Immediately below it, a refracted arrival at $4.0 \mathrm{~km} \mathrm{~s}^{-1}$ can be interpreted either as rather consolidated material or as an evaporite sequence ( $1 \mathrm{~km}$ thick). Messinian evaporites were identified from seismic reflection lines north of DSDP site 377. Messinian is thus present halfway between ESPs 8 and 9, and only $40 \mathrm{~km}$ south of ESP 9 (Hsü, Montadert et al. 1978). We consequently favour a Messinian origin for this shallow sequence with high velocity. Contrary to the other three ESPs, no velocity inversion was found below this first refracted arrival. A striking result is that high velocities prevail down to a depth of $11 \mathrm{km:} 4.75 \mathrm{~km} \mathrm{~s}^{-1}$ from 4.45 to $6.6 \mathrm{~km}$ depth, $5.0 \mathrm{~km} \mathrm{~s}^{-1}$ from 6.6 to $9.1 \mathrm{~km}$ depth, $5.5 \mathrm{~km} \mathrm{~s}^{-1}$ from $9.1 \mathrm{~km}$ to $10 \mathrm{~km}$ and finally $6.6 \mathrm{~km} \mathrm{~s}^{-1}$ down to $11 \mathrm{~km}$. Although the velocity model becomes rather speculative deeper, a velocity inversion is apparently present below $11 \mathrm{~km}$, the velocity dropping down to $4.3 \mathrm{~km} \mathrm{~s}^{-1}$. ESP 11 presents a $2 \mathrm{~km}$ thick unconsolidated sediment layer (velocity ranging from 2.0 to $4.1 \mathrm{~km} \mathrm{~s}^{-1}$ ) overlying again high-velocity material (from 4.6 to $60 \mathrm{~km} \mathrm{~s}^{-1}$ ).

The velocity models for ESPs 9 and 11 both indicate the presence of high-velocity material at shallow depth. This is in good agreement with the distribution of the shallow seismicity discussed in the previous section and the southwestward extension of the seismic front over the inner unit. The inner unit of the ridge is thus probably made of highly consolidated and brittle material, not only at depth but also at shallow levels. The transition from relatively unconsolidated material (ESP 8) to consolidated material (ESP 9) has to be rather sharp, the distance between the two ESPs being less than $80 \mathrm{~km}$. In the next section, we use gravity data to constrain a complete crustal section across the ESPs.

\section{GRA VITY MODELLING}

Fig. 7 is a Free Air Anomaly (FAA) gravity map derived from the Marine Bouguer Anomaly maps (IBCM 1989) and

OFFSET $(\mathrm{km})$

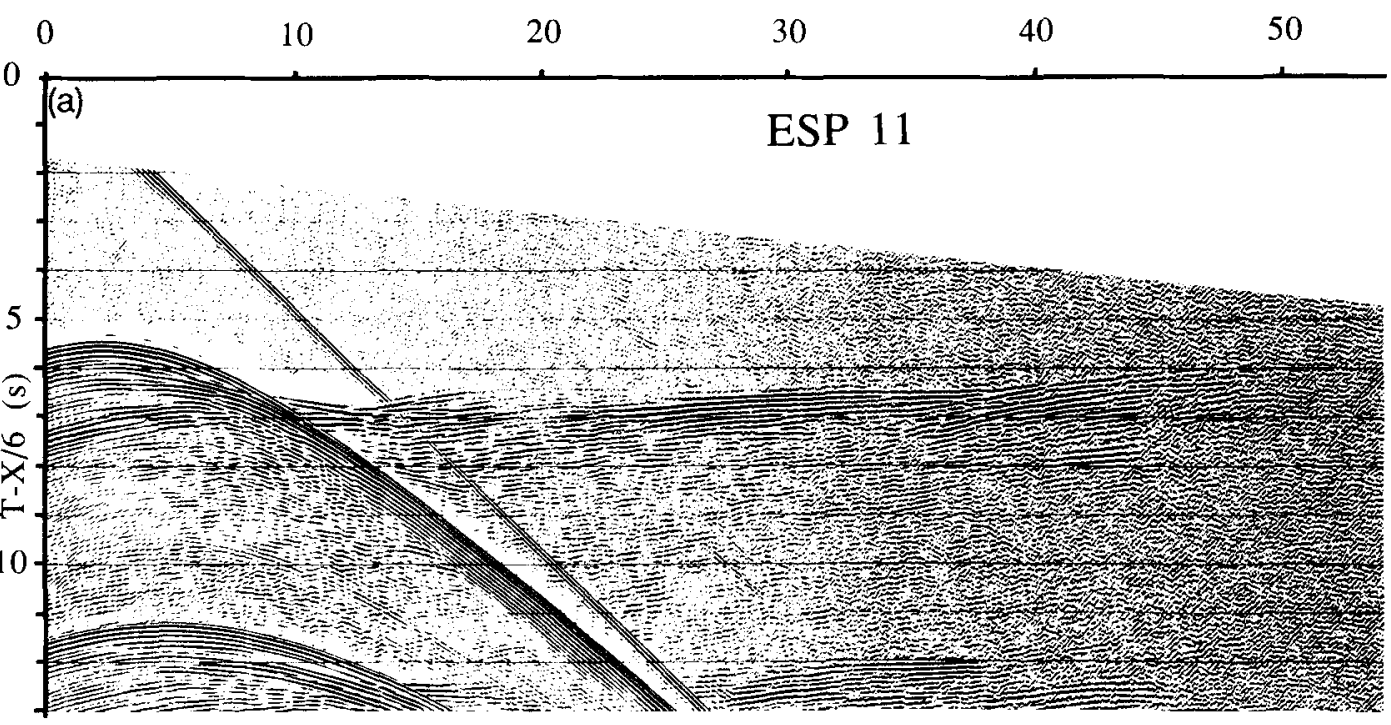

Figure 6(a). Record section for ESP 11 located on the Hellenic Trench (Fig. 1). The traveltimes are reduced by a linear phase velocity of $6 \mathrm{~km} \mathrm{~s}^{-1}$. 


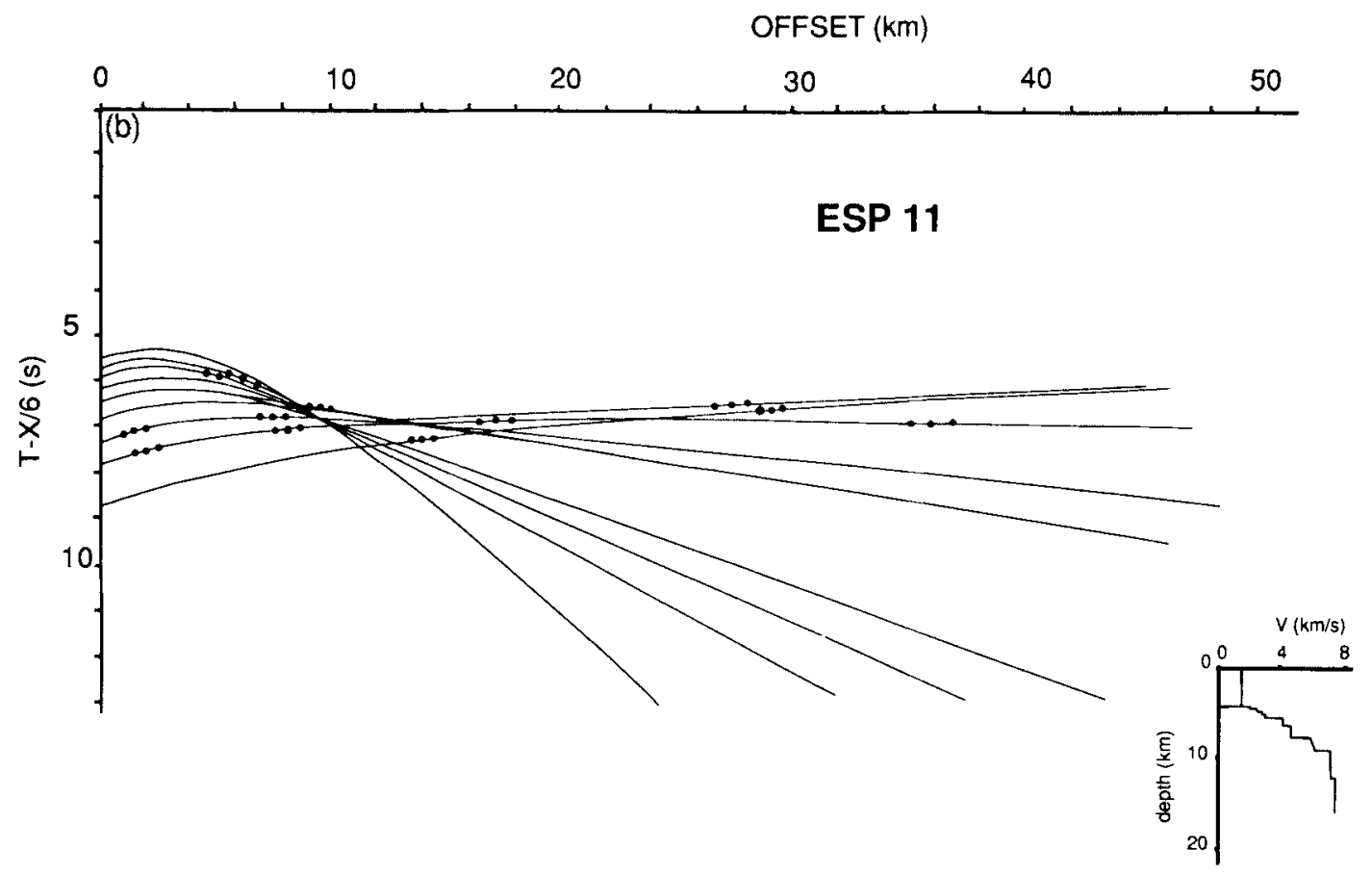

Figure 6(b). Calculated traveltime curves corresponding to the final 1-D velocity model shown on the lower right corner.

the bathymetric maps (IBCM 1981). Eight profiles were created from contours in a narrow $50 \mathrm{~km}$ wide band roughly passing through the ESPs. Fig. 8 displays the bathymetric and FAA gravity profiles. Bouguer profiles were also calculated (Fig. 8, middle) using a 2-D approximation and replacing seawater by sediments with a density of $2.2 \mathrm{~g} \mathrm{~cm}^{-3}$ (assumed to be the mean density of the sediments forming the Mediterranean Ridge topography).

From the African margin to the Sirte Abyssal Plain, the
FAA is close to the zero level (Fig. 8, bottom), indicating that the margin is close to local isostatic equilibrium. Based on the results of ESP 19, previous reflection profiles (from OGS, Finetti 1976) and on the bathymetry, the transition from the continental crust of the margin to the oceanic crust of the African plate is probably close to the Sirte Abyssal Plain on our section, slightly southwestward of ESP 19. The FAA then progressively decreases from the central part of the outer unit to the Hellenic Trench, reaching a minimum

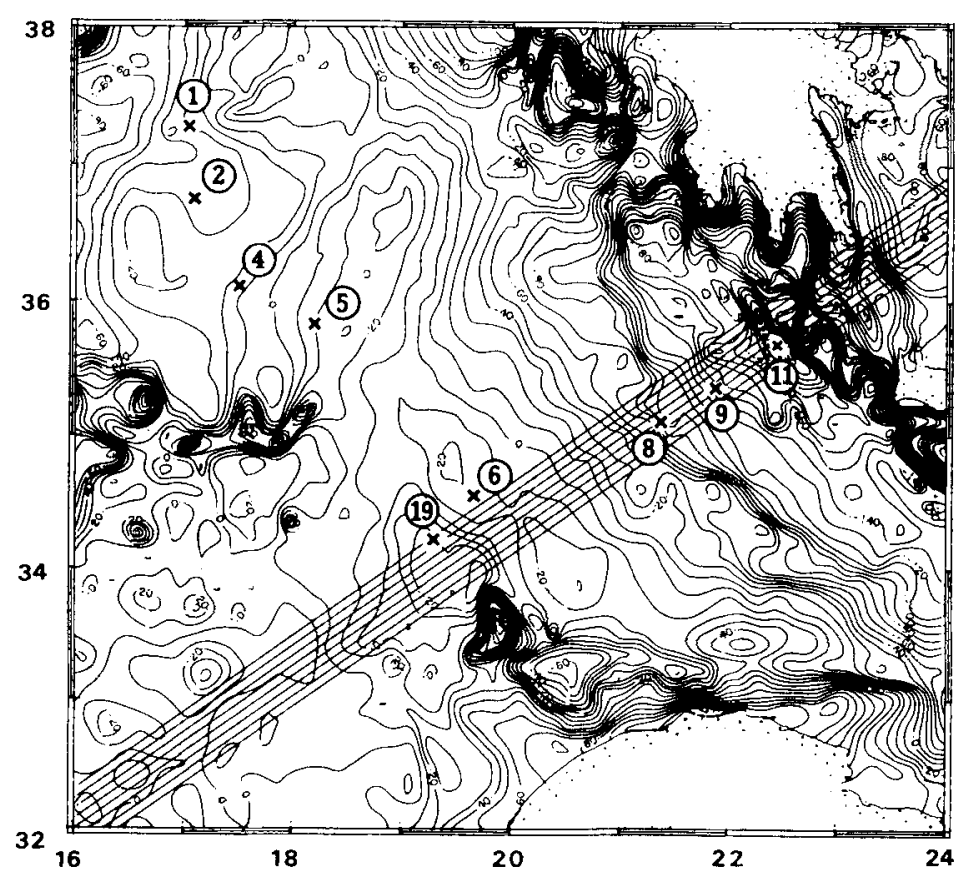

Figure 7. Free-air gravity anomaly map with the location of profiles made through the Western Mediterranean Ridge (profiles are displayed in Fig. 8). contour interval: 10 mgal. 


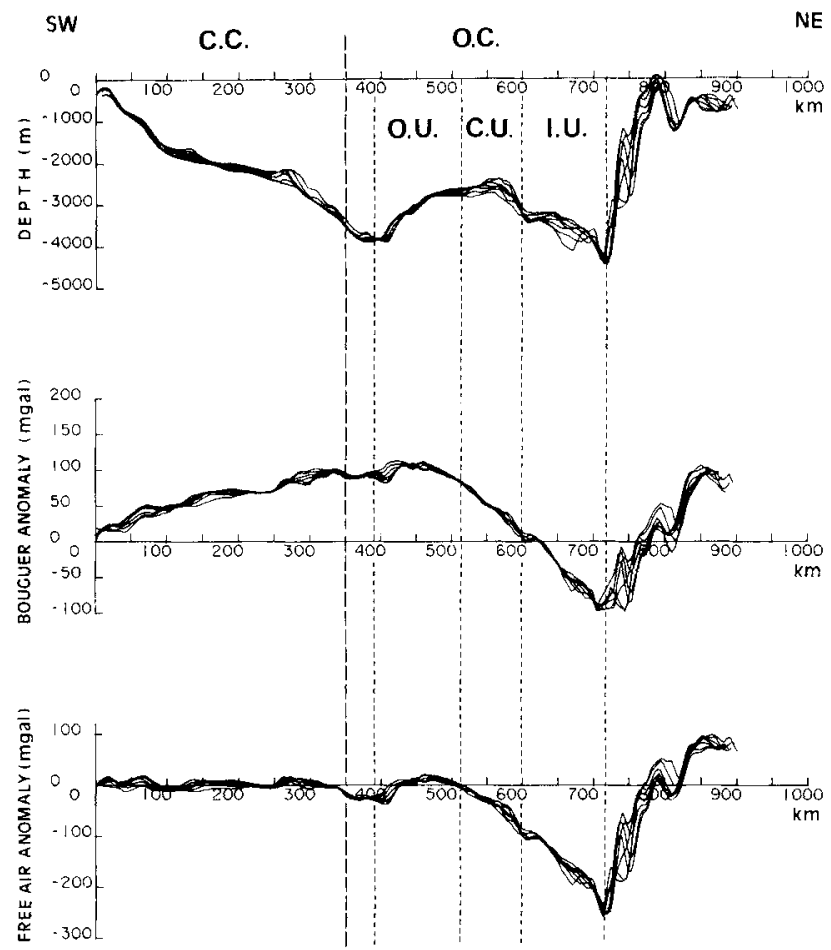

Figure 8. Top: Bathymetric profiles located as the free-air anomaly profiles on Fig. 7. Middle: Bouguer anomaly profiles calculated with a density of 2.2. Bottom: Free-Air Anomaly profiles (see Fig. 7). C.C. $=$ Continental Crust; O.C. $=$ Oceanic Crust; O.U. = Outer Unit; C.U. = Central Unit; I.U. = Inner Unit.

of $-250 \mathrm{mgal}$ in the trench itself. Notice that the relief of the Mediterranean Ridge itself does not contribute significantly to the gravity field. However, the morphologically based division of the ridge into outer, central and inner units is still reflected as small steps in the gravity field. The Bouguer profiles (Fig. 8, middle) show a remarkably simple gravity signature: increase away from the African margin and decrease across the Mediterranean Ridge starting a few tens of kilometers landward (towards Crete) of the deformation front. This can be simply interpreted as gradual shallowing of the crust-mantle boundary over the African margin and further downbending of the African oceanic lithosphere beneath the ridge.

Using available refraction and reflection seismic results and 2-D gravity modelling, we computed a crustal section across the Western Mediterranean Ridge (Fig. 9). West of ESP 19, we extend the structure found for the Sirte Abyssal Plain to infinity to avoid edge effects. For all computations, used densities have no units because they are ratio between volumetric mass of material and volumetric mass of the water. Refraction results of Makris \& Stobbe (1984) were used on the Aegean Sea side to constrain the structure, thickness and density of the lower continental crust (a density of 2.92 is adopted). Also included beneath the Aegean Sea there is a 'hot mantle' with a reduced density ( 3.2 versus 3.45 beneath the oceanic lithosphere) to take into account the active extension in the Aegean Sea. The thickness of this layer is such that the vertically integrated masses on the Sirte Abyssal Plain side and Aegean Sea side are equal, ensuring zero levels on both sides at infinity.
Finally, a body with a density contrast of $+0.6 \mathrm{~g} \mathrm{~cm}^{-3}$ at a depth of $71 \mathrm{~km}$ down to a depth of $200 \mathrm{~km}$ simulates the cold African lithospheric slab dividing into the mantle. The geometry of the slab there is taken from the seismicity results of Hatzfeld et al. (1989).

The seismic velocities obtained from ESPs along the section have been transformed into densities using a standard velocity/density law (except for the evaporitic sequence for which a density of 2.2 was assumed). As we are mainly interested in relative variations of density, our results do not significantly depend on the velocity/density law we use. For simplicity, we used Ludwig, Nafe \& Drake's (1970) compilation of experimental data for compressional velocity versus measured density. Each density model is presented next to the corresponding velocity model in Table 1 to 5 for ail ESPs. We chose a density of 3.45 for the mantle beneath it. By correlations between ESPs 19,6 and 8, and assuming no lateral variations in the densities, a simplified sedimentary section with averaged densities was built using three main sedimentary bodies; Messinian evaporites (density 2.2), shallow sediments (density 2.3) and deeper sediments (density 2.38). From ESP 19 to ESP 8, each crustal velocity was transformed into density and was used for the gravity model. Landward of ESP 8, the continental and the oceanic crust are separated in several bodies to match the complexities encountered at ESP 9 and 11. The densities used for the model are those transformed from the velocities of ESP 9 and 11 (see Tables 4 and 5). The bodies with a density of 2.39 (calculated from ESP 9) and a density of 2.7 (calculated from ESP 9 and ESP 11) have been prolongated landward. On Fig. 9, densities greater than 2.40 (except mantle densities) are shaded. This gravity model does not assume anything about the nature of the different bodies except for the Messinian evaporites. By simply transforming the velocities into densities, and assuming simple body shapes, we get a reasonable agreement with the observed gravity. Gravity modelling is thus in agreement with the presence of strong material inferred from seismicity, and with the higher velocities recorded at shallow depth at ESPs 9 and 11. We are aware that the gravity model has no unique solution, and gravity alone would not tell us much about the deep structures. However, combined with the ESP results, the solution we propose, although much simplified, is compatible with both the gravity anomaly observed and the seismic velocities inferred from the ESP.

\section{DISCUSSION AND CONCLUSION}

Fig. 10 summarizes the available information along the crustal section. The velocity models are shown next to each ESP. The bodies are those derived from the gravity modelling. Hypocentres in a $240 \mathrm{~km}$ wide band are projected onto the section. Corresponding epicentres are located in Fig. 3. We added the microseismicity from Hatzfeld et al. (1989). Large dots indicate earthquakes with focal mechanisms. The numbers next to them refer to their locations in Fig. 3.

As already discussed in plan view, the shallow seismicity along the section spreads far beyond the trenches, more than $50 \mathrm{~km}$ seaward. The location of the scismic front over 

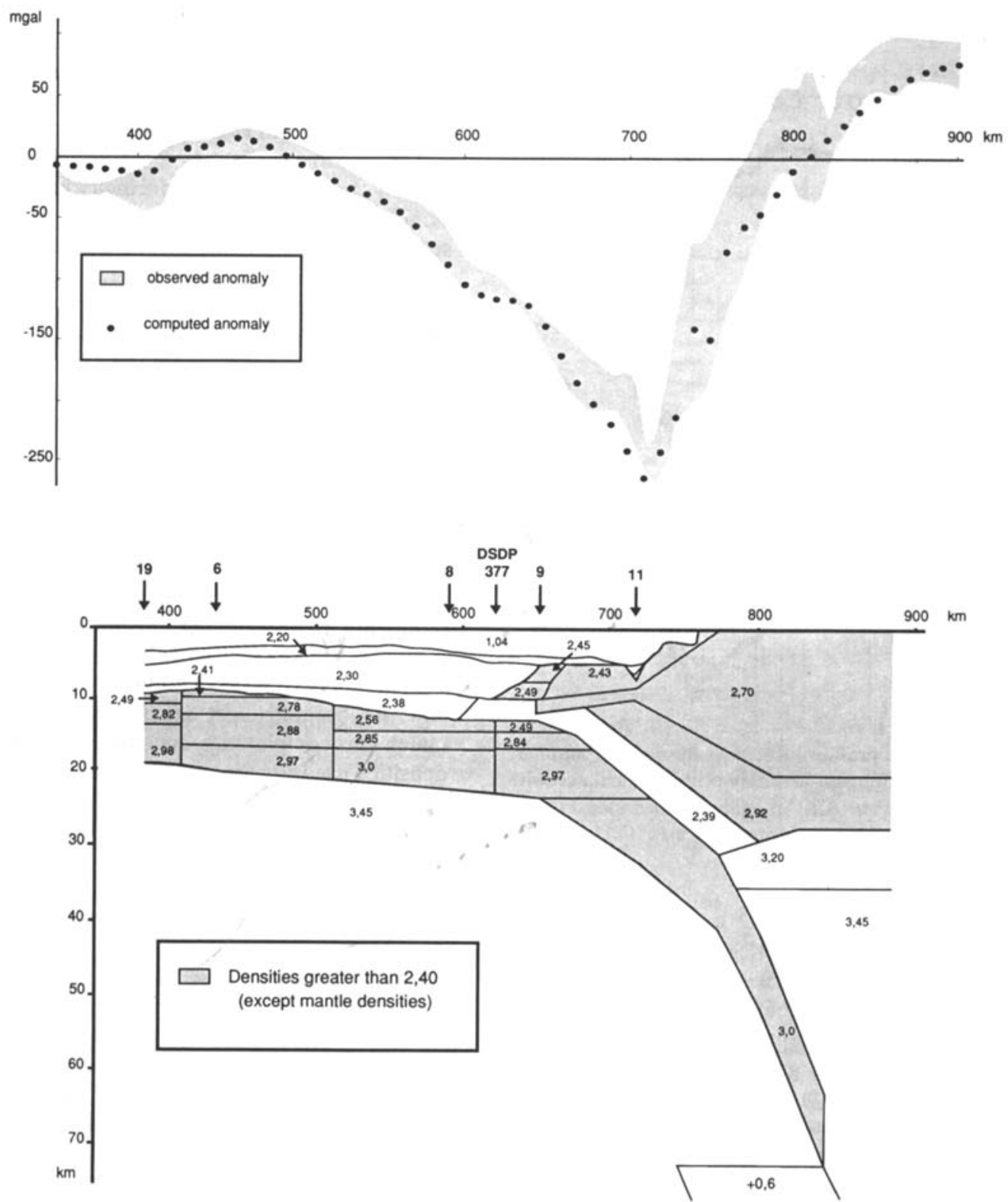

Figure 9. Gravity model: Top: observed free air anomaly profiles (Fig. 8 bottom) and calculated gravity model (large dots). Bottom: crustal model and densities used in the model.

convergent margins is generally interpreted as the extreme seaward extent of the consolidated material of the backstop (Byrne, Davis \& Sykes 1988). The seismic front is also generally coincident with the outer-arc high. However, Kastens (1991) has considered that the backstop of the Mediterranean Ridge is limited by the present continental slope and this does not extend below the trench. Note that this interpretation violates the general observation that the backstop should extend to below the summit of the outer-arc high.

Three different and independent data sets point to the presence of relatively dense and strong (brittle) material over the innermost part of the Western Mediterranean Ridge: the seaward extent of the seismicity, the high seismic velocities recorded by ESPs and the high densities inferred from gravity modelling. A logical alternative to the previously discussed continental-slope backstop hypothesis is that the inner part of the ridge itself acts as a backstop. In Fig. 9, all bodies belonging to the Mediterranean Ridge with density higher than 2.40 (except mantle densities) are shaded. They for a prismatic body, roughly corresponding to the inner unit at the surface. Although the exact shape of this body cannot be resolved using gravity, the density gradient suggests a seaward dip. Intersection at depth between this body and the subducted sediments would be close to DSDP 377, so that this is where the outer arc high should be found. Notice in Fig. 10 that this intersection is indeed close to the apex of the ridge, generally located over the central unit. This is particularly clear on most of the profiles displayed in Fig. 2. The inner unit may thus be regarded as a backstop and the central unit as the outer-arc high. The material forming the backstop (density 2.43 to 


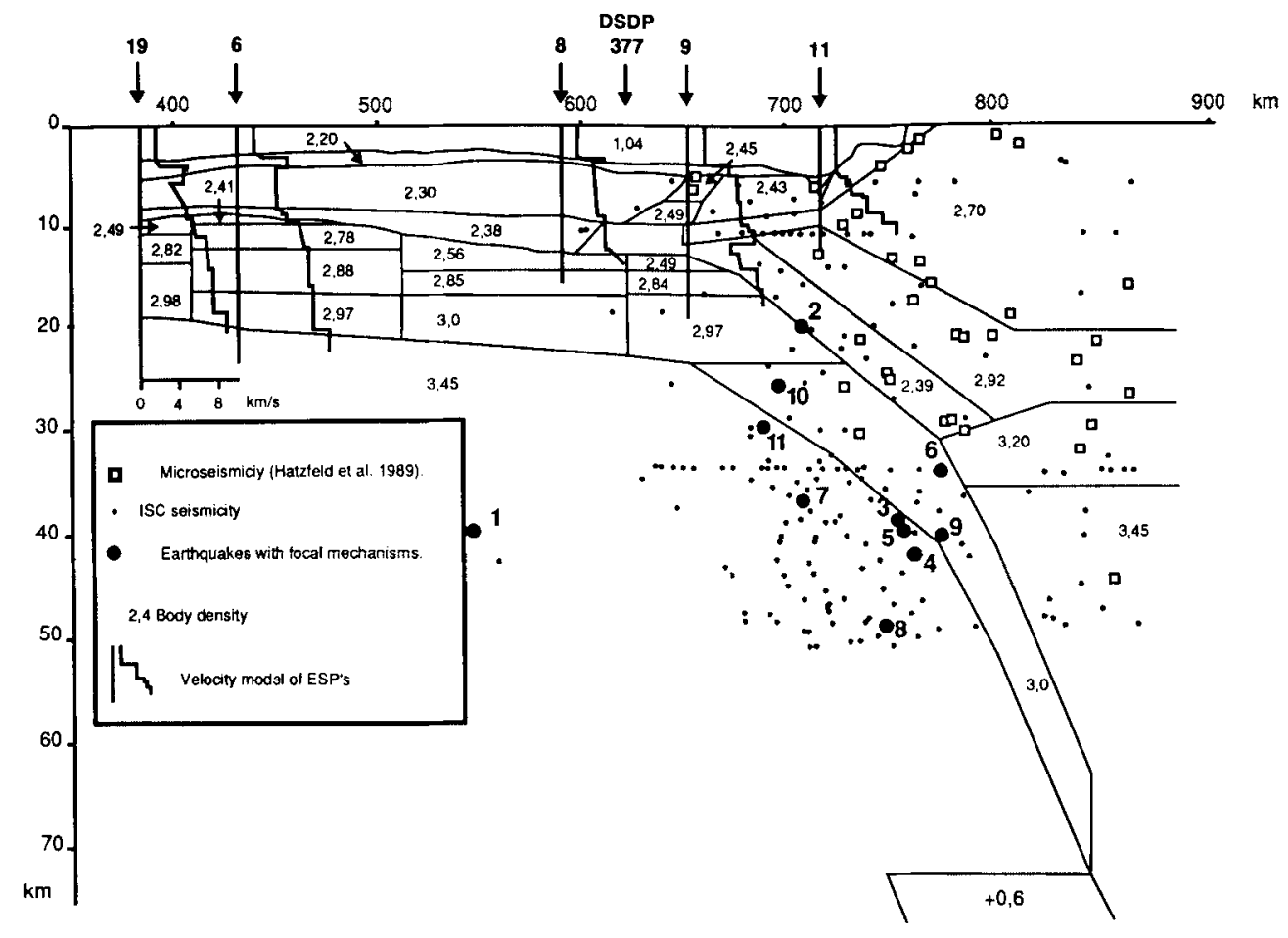

Figure 10. Summary results from the five ESPs of this transect. Velocity models of ESPs $19,6,8,9$ and 11 are displayed on the crustal cross section through the Western Mediterrancan Ridge. Horizontal scale for the ESPs is in $\mathrm{km} \mathrm{s}^{-1}$ and vertical scale in km. Horizontal scale for the crustal cross section is in $\mathrm{km}$. The location of the scams were projected on this crustal cross section from a $240 \mathrm{~km}$ wide band. Squares show the distribution of microseismicity (Hatzfeld et al. 1989) and small dots show the distribution of seisms from the ISC catalogue. The big dots numbered from 1 to 11 represent location of seisms with focal mechanisms (see Fig. 3). ESPs and DSDP 377 are located.

2.70) may be either Peloponnesus thrust sheets, thinned continental crust or consolidated sediments. We favour the thrust sheet hypothesis. Velocities encountered at ESP 9 (reaching 5.5 to $6.6 \mathrm{~km} \mathrm{~s}^{-1}$ at $10 \mathrm{~km}$ ) are much too high for a sedimentary sequence, even highly consolidated. The velocity distribution with depth is fairly complex on the inner unit, including a velocity inversion at $11 \mathrm{~km}$. The layer which creates this velocity inversion (body with a density of 2.39 ), situated above the oceanic crust and seen on ESP 19, 6,8 and 9 (ESP 11 has a velocity model only down to $12 \mathrm{~km}$ ), has been attributed to consolidated sediments subducted with the African plate. In conclusion, the inner unit of the ridge which forms the backstop off the Hellenic Trench consist of continental material, possibly thrusts sheets emplaced during Oligocene to Miocene.

\section{ACKNOWLEDGMENTS}

Seismic processing was done at IFP (Institut Français du Pétrole). We thank D. Hatzfeld from the Observatoire de Grenoble (IRIGM) who provided us with the digital microseismicity data used in Fig. 10. A. Nicolich from the O.G.S. of Trieste kindly supplied us with a copy of their reflection line MS33. P. Henry is acknowledged for helpful discussion on the Mediterranean Ridge prism. We are grateful to two anonymous reviewers for their constructive comments.

\section{REFERENCES}

Biju-Duval, B., Letouzey, J. \& Montadert, L., 1978. Structure and evolution of the Mediterranean basins, in Initial reports of the Deep Sea Drilling Project, Vol. 42, Part 1, pp. 951-981, eds Hsiu, J., Montadert, L. et al., Government Printing Office, Washington, DC.

Bonneau, M., 1984. Correlation of the Hellenic nappes in the south-east Aegean and their tectonic reconstruction, in The Geological Evolution of the Eastern Mediterranean, pp. 517-527, eds Dixon, J. E. \& Robertson, A. H. F., Special Publication of the Geological Society of London, Vol. 17, Blackwell Scientific Publications, Oxford.

Byrne, D. E., Davis, D. M. \& Sykes, L. R., 1988. Loci and maximum size of thrusts earthquakes and the mechanisms of the shallow region of subduction zones, Tectonics, 7, 833-857.

Camerlenghi, A., Cita, M. B., Hieke, W. \& Ricchuito, T. S., 1992. Geological evidence of mud diapirism on the Mediterranean Ridge acceretionary complex. Earth planet. Sc. Lett., 109, 493-506.

Davis, D. M., Suppe, J. \& Dahlen, F. A., 1983. Mechanics of fold-and-thrust belts and accretionary wedges, J. geophys. Res., 88, $1153-1172$.

de Voogd, B., Truffert, C., Chamot-Rooke, N., Huchon, P., Lallemant, S. \& Le Pichon, X., 1992. Two-ship deep seismic soundings in the basins of the Eastern Mediterranean Sea (Pasiphae Cruise), Geophys. J. Int., 109, 536-552.

Dziewonski, A. M., Friedman, A. \& Woodhouse, J. H., 1983a. Centroid-moment tensor solutions for January-March, 1983, Phys. Earth. planet. Inter., 33, 71-75. 
Dziewonski, A. M., Friedman, A., Giardini, D. \& Woodhouse, J. H., 1983b. Global seismicity of 1982: centroid-moment tensor solutions for 308 earthquakes, Phys. Earth. planet. Inter., 33, 76-90.

Dziewonski, A. M., Franzen, J. E. \& Woodhouse, J. H., 1985. Centroid-moment tensor solutions for April-June, 1984, Phys. Earth. planet. Inter, 37, 87-96.

Dziewonski, A. M., Franzen, J. E. \& Woodhouse, J. H., 1986. Centroid-moment tensor solutions for July-September 1985, Phys. Earth. planet. Inter., 42, 205-214.

Finetti, I., 1976. Mediterranean Ridge: a young submerged chain associated with the Hellenic Arc, Boll. Geophys. Teor. Appl., 14, 291-342.

Genthon, P. \& Souriau, M., 1987. New constraints on Aegean subduction from Seasat altimetry, $J$. geophys. Res,, 92, 619-632.

Hall, R., Audley-Charles, M. G. \& Carter, D. J., 1984. The significance of Crete for the evolution of the Eastern Mediterranean, Special Publications of the Geological Society of London, pp. 499-516, 17, Blackwell Scientific Publications, Oxford.

Hatzfeld, D., Besnard, M., Makropoulos, K. \& Hatzidimitriou, P., 1993. Microearthquake seismicity and fault plane solutions in the southern Aegean and its geodynamics implications, Geophys. J. Int., submitted.

Hatzfeld, D., Pedotti, G., Hatzidimitrian, P., Panagiopoulos, D., Scordilis, M., Drakopoulos, I., Makropoulos, K., Delibasis, N., Latousakis, I., Baskoutas, J. \& Frogneux, M., 1989. The Hellenic subduction beneath the Peloponnesus: first results of a microearthquake study, Earth planet Sci. Lett., 93, 283-291.

Hsü, K. J., Montadert, L. et al., 1978. Initial reports of the Deep Sea Drilling Project, 42, Washington DC, 1053-1079.

INTERNATIONAL BATHYMETRIC CHART of the MEDITERRANEAN 1981. Bathymetric map published by the Head department of navigation and oceanography ministry of defence, Leningrad, USSR, under the authority of IOC.

INTERNATIONAL BATHYMETRIC CHART of the MEDITERRANEAN 1989. Bouguer gravity anomalies, Bouguer density of $2.67 \mathrm{~g} \mathrm{~cm}^{-3}$ published by the Head department of navigation and oceanography ministry of defence, Leningrad, USSR, under the authority of IOC.
Kastens, K., 1991. Rate of outward growth of the Mediterranean Ridge Accretionnary Complex, Tectonophysics, 109, 25-50.

Lallemant, S., Truffert, C., Jolivet, L., Henry, P., Chamot-Rooke, N. \& de Voogd, B., 1992. Spatial transition from compression to extension in the Western Mediterranean Ridge Accretionary Complex, Tectonophysics, submitted.

Le Pichon, X. \& Angelier, J., 1979. The Hellenic arc and Trench system: a key to the neotectonic evolution of the Eastern Mediterranean area, Tectonophysics, 60, 1-42.

Le Pichon, X., Mascle, J. \& Augustithis, S. S., 1982. Special Issue, Tectonophysics, 86.

Le Pichon, X., Lyberis, N., Angelier, J. \& Renard, V., 1982. Strain distribution over the East Mediterranean Ridge: a synthesis incorporating new Sea Beam Data, Tectonophysics, 86, 243-274.

Ludwig, W. J., Nafe, J. E. \& Drake, C. L., 1970. Seismic refraction, in The Sea., Vol. 4, pp. 53-84, ed. Maxwell, A. E.

Makris, J. \& Stobbe, C. 1984. Physical properties and state of the crust and upper mantle of the eastern Mediterranean sea deduced from geophysical data, Mar. Geol., 55, 347-363.

Montadert, L., Letouzey, J. \& Mauffret, A., 1978. Messinian event: seismic evidence, in Initial reports of the Deep Sea Drilling Project, Vol. 42, Part 1, pp. 1037-1050, eds Hsü, K. J. Government Printing Office, Washington, DC.

Papadopoulos, T., Wyss, M. \& Schmerge, D. L., 1988. Earthquake locations in the Western Hellenic Arc relative to the plate boundary, Bull. seism. Soc. Am., 78, 1222-1231.

Papazachos, B. C., Kiratzi, A. A., Hatzidimitriou, P. M. \& Rocca, A. C., 1984. Seismic faults in the Aegean area, Tectonophysics, 106, $71-85$.

Pedotti, G., 1988. Etude sismotectonique du Peloponnèse, Thése d'Université de Grenoble.

Robertson, A. H. F. \& Dixon, J. E., 1984. Introduction: aspects of the geological evolution of the Eastern Mediterranean, in Special Publications of the Geological Society of London, 17, pp. 1-74, Blackwell Scientific Publications, Oxford.

Ryan, W., Kastens, K. \& Cita, M. B., 1982. Geological evidence concerning compressional tectonics in the eastern Mediterranean, Tectonophysics, 86, 213-242.

Taymaz, T., Jackson, J. \& Westaway, R., 1990. Earthquake mechanisms in the Hellenic Trench near Crete, Geophys. J. Int., 102, 695-731. 